\title{
Modeling Africa's Demand for Iron and Steel Importation: An International Market Estimation Method Perspective
}

\author{
Fidelys Ravelomanana1, Liang Yan', Christophe Mahazomanana', Leoncine Paul Miarisoa ${ }^{2}$ \\ ${ }^{1}$ School of Economics and Management, China University of Geosciences (Wuhan), Wuhan, China \\ ${ }^{2}$ Lingnan (University) College, Sun Yat-sen University, Guangzhou, China \\ Email: fidelys@hotmail.com, mahazomanana@hotmail.com, mleoncine@hotmail.com
}

Received 19 November 2014; revised 5 December 2014; accepted 20 December 2014

Copyright (C) 2014 by authors and Scientific Research Publishing Inc.

This work is licensed under the Creative Commons Attribution International License (CC BY). http://creativecommons.org/licenses/by/4.0/

\section{Open Access}

\section{Abstract}

This paper describes the first part of my PhD research project where Africa's Demand for Iron and Steel Importation Long-Term Relationship with its explanatory variables is investigated. We employ a panel of 19 African countries for a period that spans from 1994 to 2012 . We consider the long-term relationship that may exist between the iron and steel importations and the explanatory variables used (GDP per capita, investment in infrastructure, real effective exchange rate, and the number of urban population). The empirical analysis is divided in three parts in this study. In the first part, the panel unit root tests and stationary tests revealed that all variables have a unit root; in first differences, they are stationary, these variables are integrated of order 1 or I (1) and the level of the variables are I (1). In the second part, the different cointegration tests conducted between the dependent variable and the explanatory variables result in the confirmation of the fact that they are cointegrated. In the third part, an estimation of the long-run relationship is carried out with Panel Error Correction Modeling (ECM) using Pooled Mean Group Regression Methods. The importations of iron and steel are positively correlated with all the independent variables of the model. All estimated coefficients are positive and significant at $1 \%$ level of significance. The usual determinants of importations (demand factor and factor price competitiveness) are significant in the modeling of iron and steel importations and signs are consistent with expectations except the real effective exchange rate.

\section{Keywords}

Africa's Demand for Iron and Steel Importation, Panel Unit Roots, Panel Cointegrations, Panel Error Correction Modeling (ECM), Pooled Mean Group (PMG) Regression Methods 


\section{Introduction}

The process of evaluating worldwide export opportunities is complicated for a number of reasons. These include the difficulty of examining all possible export opportunities to all the countries of the world and the availability of data for specific consumers, businesses or governments that limits the screening process to using only published data [1] [2]. Numerous attempts to formulate appropriate international market selection processes have been made in the literature.

Papadopoulos and Denis [3] summarized the literature on international market selection methods up until the late 1980s. They classified over 40 proposed international market selection models into two broad types of approaches-qualitative approaches (rigorous and systematic gathering and analysis of qualitative information about one or a handful of potential country markets) and quantitative approaches (analyzing large amounts of secondary statistical data about many or all foreign markets). In Figure 1 this categorization is illustrated.

According to Papadopoulos and Denis [3] most qualitative approaches typically start with identifying a short list of countries for further consideration by establishing objectives and constraints for exporting a specific product to each country under consideration. Other studies focus more on the nature, appropriateness and sources of qualitative information that could be used in the international market selection process. These sources include government agencies, chambers of commerce, banks, distributors, customers, international experts and foreign market visits [4]. Papadopoulos and Denis [3] suggest that pure qualitative approaches to international market selection could be seen as biased as they are based on perceptions and are largely inaccurate.

Douglas et al. [5] stated that the biggest challenge in international market selection is the large number of countries throughout the world that need to be analyzed. They suggest that a screening procedure of secondary data be used to determine which countries to investigate in depth. Quantitative approaches to international market selection do exactly this by analyzing and comparing secondary data of a large number of countries and will be discussed subsequently.

Papadopoulos and Denis [3] further divided quantitative approaches into two categories, namely market grouping methods and market estimation methods. Market grouping methods cluster countries on the basis of similarity while market estimation models evaluate market potential on firm or country level (see Figure 1). This current study can be classified as quantitative approaches and market estimation methods.

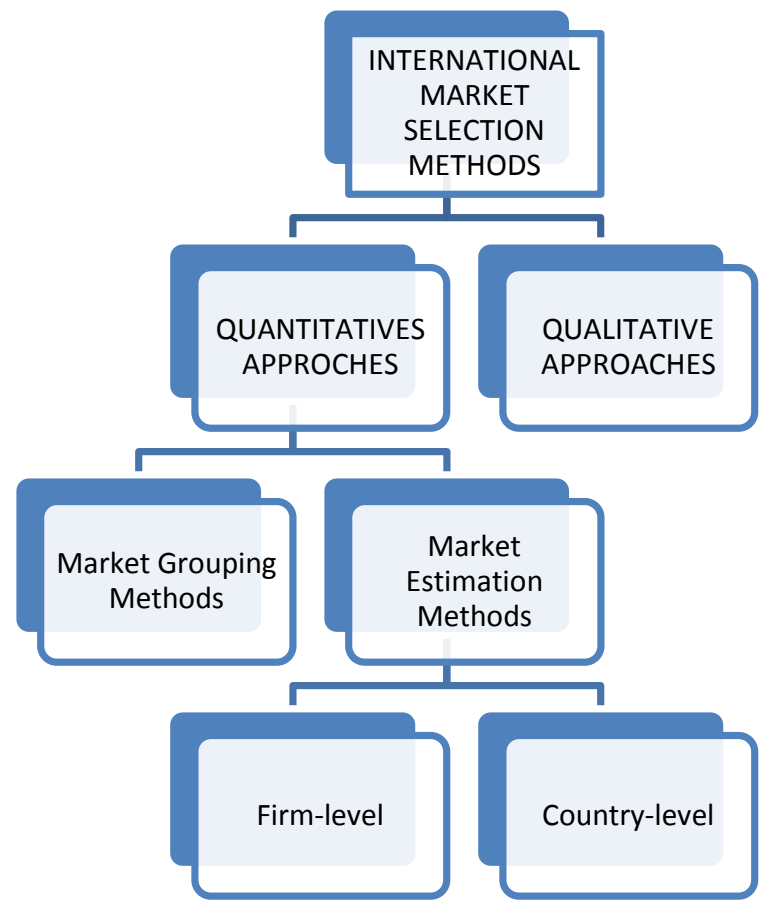

Source: Authors own figure constructed from Papadopoulos and Denis [3].

Figure 1. Categorization of the international market selection literature. 
This current study is a part of my $\mathrm{PhD}$ research project with which we reviewed literatures on international market selection methods to find the international market selection methods best-suited to analyzing African Iron and Steel Market for Wuhan Iron and Steel Corporation (WISCO)'s International Market Selection entering African Iron and Steel Market.

But the main purpose of the present paper is to buildan econometric model for analyzing African Iron and Steel Market for Wuhan Iron and Steel (WISCO)'s International Market Selection. We will estimate Africa's Demand for Iron and Steel Importation by Panel Error Correction Modeling (ECM) using Pooled Mean Group (PMG) regression methods.

\section{Literature Review}

The literature on quantitative approaches to international market selection methods will be discussed in this section under different categories (Figure 1).

\subsection{Market Grouping Methods}

Studies undertaken to attempt market grouping have been summarized by Papadopoulos and Denis [3], Steenkamp and Ter Hofstede [6], and Shankarmahesh et al. [7]. These methods are based on the assumption that the most attractive markets for a firm are the ones that most closely resemble the markets it has already penetrated successfully [3]. By providing insight into structural similarities, these methods enable firms to standardize their offerings and marketing strategies across markets [8]. Countries are clustered based on similarities in social, economic and political indicators while demand levels are, for the most part, not taken into account [8]. Market grouping methods are mostly criticized for relying exclusively on general country indicators, rather than on product-specific market indicators, as macro indicators may not reflect market development for a product [3] [8] [9]. Studies that attempted to include more product-specific information faced the problem of insufficient data, and are limited to the product ranges of a particular firm. Thus, they cannot be applied to all possible product groups [3]. Sakarya et al. [8] also argued that grouping methods fail to take into account similarities among groups of consumers across national boundaries. Furthermore, focusing only on countries with similar characteristics to markets already penetrated may hold the risk of overlooking lucrative opportunities in countries with other characteristics [9].

Referring to the abovementioned limitations, market-grouping methods will not be suitable to identify export opportunities for a country if the trade promotion organization or researcher needs to consider all possible country-product combinations worldwide.

Market estimation methods will therefore be subsequently investigated in order to establish if the international market selection method best suited to the identification of potential export opportunities can be found within this classification of international market selection methods.

\subsection{Market Estimation Methods}

Market estimation models evaluate foreign markets on the basis of several criteria that measure aggregate market potential and attractiveness [3] [8]. The criteria vary across methods and often include wealth, size, growth, competition and access indicators [8]. Papadopoulos and Denis [3] summarized the different methods of measuring market potential that were introduced up until the late 1980s and included multiple factor indices, regression analyses and multiple criteria import demand estimations. Papadopoulos and Denis [3] found that common shortcomings of these methods include the lack of product specificity, the assumption of a static environment and methodological problems due to data availability.

Henceforth, the more recent literature on market estimation methods will be discussed in detail. Most of these methods are based on, and address, the methodological shortcomings of earlier studies (see Papadopoulos and Denis [3] for a discussion of these earlier studies).

For the purposes of this study, the literature on market estimation methods will be categorized into firm-level and country-level methods (see Figure 1). Firm-level methods can be applied by firms to identify markets for their limited product ranges. These methods usually include an analysis of the firm's objectives, profitability, managerial experience and knowledge, customer standards and attitudes and product adaptation requirements when identifying potential export markets. Country-level methods, on the other hand, can be applied by a coun- 
try's export promotion agency to identify the most promising country-product combinations to focus their export promotion efforts on. Criteria and data used in these methods should be product-specific, applicable to many country-product combinations and generally available. These criteria might include product-specific market growth, market size, level of competition and barriers to trade.

\subsubsection{Firm Level Market Estimation Methods}

Firm-level market estimation methods are applied by firms to identify markets for their limited product ranges. These methods usually include an analysis of the firm's objectives, profitability, managers' experience and knowledge, customer standards and attitudes and product adaptation requirements when identifying potential export markets. Apart from the older studies summarized by Papadopoulos and Denis [3], firm-level market estimation methods include the studies of Ayal and Zif [10]-[12], Kumar et al. [9], Hoffman [13], Andersen and Strandskov [14], Brewer [2], Andersen and Buvik [15], Rahman [16], Alon [17], Ozorhon, Dikmen and Birgonul [18] and more.

Most of these studies are based on the following three-stage process of evaluating the export potential of foreign markets:

1) A preliminary screening to select more attractive countries to investigate in detail, based on countries' demographic, political, economic and social environment;

2) An in-depth screening in which these products' potential (market size and growth), competitors, market access and other market factors for the countries selected in stage one are analyzed;

3) A final selection that involves the analysis of company sales potential, profitability and possible product adaptation.

\subsubsection{Country-Level Market Estimation Methods}

Apart from the Decision Support Model [19]-[21], nine other studies can be found that can be classified as country-level market selection methods. The main criterion for a market selection method to be classified into this category is that it should be capable of screening a wide range of product-country combinations to select export markets with realistic potential for a specific exporting country.

The methods that, on first review, seemed to comply with this criterion include:

$\checkmark$ the shift-share model of Green and Allaway [22],

$\checkmark$ the global screening model of Russow and Okoroafo [23],

$\checkmark$ the trade-off model of Papadopoulos, Chen and Thomans [24],

$\checkmark$ the multiple criteria method of the International Trade Centre (ITC) [25]-[29],

$\checkmark$ the assessments of export opportunities in emerging markets by Cavusgil [30]-[32], Arnold and Quelsh [29] and Sakarya et al. [8],

$\checkmark$ the gravity model and the trade opportunity matrix (TOM) of Export Development Canada [33].

\subsection{Summary of Literature Review}

Papadopoulos and Denis [3] summarized the literature on international market selection methods up until the late 1980s. They classified over 40 proposed international market selection models into two broad types of approaches-qualitative approaches (rigorous and systematic gathering and analysis of qualitative information about one or a handful of potential country markets) and quantitative approaches (analyzing large amounts of secondary statistical data about many or all foreign markets). This current study can be classified as quantitative approach.

The literature on market estimation methods were categorized into firm-level and country-level methods (see Figure 1). Firm-level methods can be applied by firms to identify markets for their limited product ranges. Country-level methods, on the other hand, can be applied by a country's export promotion agency to identify the most promising country-product combinations to focus their export promotion efforts on. Our study can be classified in Firm-level market estimation methods, as the purpose of this study is to find the international market selection method best-suited to analyzing African Iron and Steel Market for WISCO's International Market Selection.

We adapted the firm level market estimation methods' three-stage process of evaluating the export potential of foreign markets as follow: Modeling Africa's Demand for Iron and Steel Importation, a preliminary screening 
and a final selection. Modeling Africa's Demand for Iron and Steel Importation is the main purpose of the present study.

Most of the existing models of International Market Selection are country-level market estimation methods. No previous studies was conducted in firm-level market estimation methods for single steel industry, neither for Africa steel industry, thus no model is available for us to analyzing African Iron and Steel Market for WISCO's International Market Selection. So, we need to build our own Econometric Model to allow us analyzing our case study.

\section{Modeling Africa's Demand for Steel Importation}

\subsection{Definitions and Concepts}

Gross domestic product or GDP is the total value of goods and services produced, and will no longer enter into any production process, for a country for a given period, is generally one year. It is used to measure the economic growth of a country. It is measured by giving a monetary value to each item produced by a country; then sum up the monetary value, and we get the value of GDP. GDP per capita is the ratio between the value of total GDP and the number of the average population of a year.

Public investments are part of the economic aggregate like public expenditure, investments considered part of a "non-market" products (roads, justice, police, public lighting, public education and research, national defense, etc.), and secondly by the grant of a portion of the accumulation of technological business capital, whether public or private.

Here we will look to public infrastructure investments. To measure these, we will be interested in GFCFGross Fixed Capital Formation, which also includes the accumulation of productive capital by businesses and housing purchases by households and acquisitions of public facilities by a country.

GFCF is a key variable in the economy of a country. The more it represents a significant share of GDP (Gross Domestic Product), the more the pace of economic growth in the country is higher.

Real effective exchange rate-REER is the weighted average of a country's currency relative to an index or basket of other major currencies adjusted for the effects of inflation. The weights are determined by comparing the relative trade balances, in terms of one country's currency, with each other country within the index.

Urban population refers to peoples whose live in urban areas as defined by the National Institute of Statistics.

\subsection{Data}

In this study, the data used are observations of macroeconomic variables, such as GDP per capita, the index of consumer prices, import iron, the real effective exchange rate, the number of urban population, imports and exports total made on 19 African countries. The values for these variables are positive, and to simplify the calculations, we will use their logarithms. The countries concerned are: Algeria, Burkina Faso, Ivory Coast, Egypt, Madagascar, Malawi, Mali, Mauritius, Morocco, Mozambique, Niger, Nigeria, Senegal, the Seychelles, South Africa, Tanzania, Togo, Tunisia, and Zambia.

Trade considered are those made with its major trading partners, including China, France, Germany, Italy, Spain, the United Kingdom and then the United States. These observations were made over a period of 19 years from 1994 to 2012. These countries were chosen because of their large share of imports and exports of iron and steel compared to all African countries but also by the availability of statistical data in the competent institutions.

Data for Iron and steel importation and exportation of these countries were drawn from the database of the UN Comtrade.

GDP per capita, total imports and exports, investment in infrastructure, the index of domestic consumer prices, the number of urban population and the exchange rate were drawn from the database of the WDI "World Development Indicators” of the World Bank, December 18, 2013.

The real effective exchange rate was calculated from the domestic and foreign price indexes, the multilateral nominal exchange rate is calculated using exchange rates provided by the WDI (World Development Indicators), and the imports and exports with partners of the considered African countries provided by the UN Comtrade (see Appendix for the formula).

GDP per capita, imports, exports, infrastructure investments are expressed in current US dollars. Exchange 
rates are quoted on the uncertain relative to the US dollar.

The index of foreign consumer price is calculated from the price index of domestic partners of Africa and the weights are their shares of trade with Africa composite index (see Appendix for the formula).

\subsection{Methodology}

We are seeking to establish long-term relationship that may exist between the iron and steel importations and the explanatory variables used (GDP per capita, investment in infrastructure, real effective exchange rate, and the number of urban population).

The empirical analysis is divided in three parts. In the first part, through panel unit roots tests we examine for the existence of panel unit roots in the variables. In the second part, panel cointegration tests investigate the existence long-run relationship of a distribution of logarithm of the imports of iron and steel and the explanatory variables used (GDP per capita, investment in infrastructure, real effective exchange rate, and the number of urban population). In the third part, estimation of the long-run relationship is carried out with Panel Error Correction Modeling (ECM) using Pooled Mean Regression.

First, It is necessary to conduct panel unit roots tests and stationary test, in order to overcome the problems with false regressions [34] [35]. Then, we stationnarize the variables of a unit root because they are misleading in the interpretations of the modeling results. Indeed, it may happen that two variables that are theoretically uncorrelated have a significantly non-zero coefficient, regressing on one another, where they assume a unit root (non-stationary); the interpretation of such a coefficient is incorrect. The different stationary tests used will be presented later.

Secondly, we perform cointegration tests between the dependent variable and the explanatory variables. It is exploring the possibility that these variables follow the same stochastic trend (indicating the existence of a long-term relationship). These tests are only performed when all variables are integrated of the same order [36].

And then, estimation of the long-run relationship is carried out with Panel Error Correction Modeling (ECM) using Pooled Mean Group Regression Methods as a part of our Long-Run Models.

\section{Empirical Findings}

In the next section we present and discuss the empirical findings. For this reason, we follow the same three parts described in previous section, which refer to the methodology used in the paper, that is 1) panel unit root tests, 2) panel cointegration tests, and 3) long-run models based on Panel Error Correction Modeling (ECM) using Pooled Mean Regression.

\subsection{Panel Unit Roots Tests and Stationary Tests}

First of all, the five variables (logarithm of iron and steel import, logarithm of GDP per capita, logarithm of infrastructure investment, the logarithm of the real effective exchange rate and the logarithm of the number of urban population) are tested for the existence of unit roots in levels and in first differences. There are two types of Panel Unit root tests, one category that is aimed at checking the existence of a common unit root for all the cross sections (Common Unit root tests) and the other category that is aimed to investigating the existence of an individual unit root for each cross-section of the panel (Individual Unit root tests). The Common Unit root tests used are the LLC test [37] and the Breitung test [38]. The Individual Unit root tests are the IPS test [39], the FisherAugmented Dickey Fuller (Fisher ADF) test [40] [41] and the Fisher-Phillips Peron (Fisher PP) test. These tests are based on the hypothesis of inter-individual independence of residues.

Table 1 shows the results of the unit root test carried out in level. The results of unit root test on the variables enable us to confirm the presence of a unit root in panel data (limp_f for logarithm of iron and steel import, lgdpcap for logarithm of GDP per capita, Linv for logarithm of infrastructure investment, ltcer for logarithm of the real effective exchange rate, and lurbpop for the logarithm of the number of urban population); the tests are carried out in levels. So we have to differentiate each variable and lead the unit root test in first differences. Table 2 shows the results of the unit root test in first differences.

The general conclusion that can be revealed from the panel unit root tests and stationary tests are that all variables have a unit root; in first differences, they are stationary, these variables are integrated of order 1 or I (1) and the level of the variables are I (1), so we can carry out the second part of the empirical analysis (Panel 
Table 1. Panel unit root tests for the levels of the variables (unbalanced set).

\begin{tabular}{|c|c|c|c|c|c|c|c|c|c|c|c|}
\hline \multicolumn{12}{|c|}{ Panel unit root tests (Unbalanced set)—levels } \\
\hline \multirow{2}{*}{ Variable } & \multirow{2}{*}{ Tests } & \multicolumn{2}{|c|}{ LLC } & \multicolumn{2}{|c|}{ Breitung-t } & \multicolumn{2}{|c|}{ IPS-W } & \multicolumn{2}{|c|}{ ADF } & \multicolumn{2}{|l|}{ PP } \\
\hline & & Stat & Prob & Stat & Prob & Stat & Prob & Stat & Prob & Stat & Prob \\
\hline \multirow{3}{*}{ limp_f } & $\begin{array}{l}\text { Individual } \\
\text { effects }\end{array}$ & 0.96 & 0.83 & & & 4.09 & 1.00 & $\begin{array}{c}8.52 \\
\text { (chi-square) }\end{array}$ & 1.00 & $\begin{array}{c}23.25 \\
\text { (chi-square) }\end{array}$ & 0.97 \\
\hline & & & & & & & & & & & \\
\hline & $\begin{array}{l}\text { Individual } \\
\text { linear trend }\end{array}$ & $-2.44^{* * * *}$ & 0.007 & $-2.428^{* * * *}$ & 0.008 & -1.17 & 0.12 & $\begin{array}{c}45.31 \\
\text { (chi-square) }\end{array}$ & 0.19 & $\begin{array}{l}104.05^{* * *} \\
\text { (chi-square) }\end{array}$ & 0.00 \\
\hline \multirow[b]{2}{*}{ Lgdpcap } & $\begin{array}{l}\text { Individual } \\
\text { effects }\end{array}$ & 1.26 & 0.90 & & & 4.56 & 1.00 & $\begin{array}{c}7.73 \\
\text { (chi-square) }\end{array}$ & 1.00 & $\begin{array}{c}10.36 \\
\text { (chi-square) }\end{array}$ & 1.00 \\
\hline & $\begin{array}{l}\text { Individual } \\
\text { linear trend }\end{array}$ & $-1.94^{* *}$ & 0.03 & $-2.12^{* *}$ & 0.02 & $-1.32^{*}$ & 0.09 & $\begin{array}{c}43.42 \\
\text { (chi-square) }\end{array}$ & 0.25 & $\begin{array}{c}21.57 \\
\text { (chi-square) }\end{array}$ & 0.99 \\
\hline \multirow{3}{*}{ Linv } & $\begin{array}{l}\text { Individual } \\
\text { effects }\end{array}$ & 2.13 & 0.98 & & & 5.85 & 1.00 & $\begin{array}{c}5.54 \\
\text { (chi-square) }\end{array}$ & 1.00 & $\begin{array}{c}8.81 \\
\text { (chi-square) }\end{array}$ & 1.00 \\
\hline & & & & & & & & & & & \\
\hline & $\begin{array}{l}\text { Individual } \\
\text { linear trend }\end{array}$ & 0.24 & 0.59 & 0.99 & 0.84 & 1.39 & 0.92 & $\begin{array}{c}24.02 \\
\text { (chi-square) }\end{array}$ & 0.96 & $\begin{array}{c}29.23 \\
\text { (chi-square) }\end{array}$ & 0.0 .84 \\
\hline \multirow{2}{*}{ Ltcer } & $\begin{array}{l}\text { Individual } \\
\text { effects }\end{array}$ & $-2.83^{* * * *}$ & 0.00 & & & -0.91 & 0.18 & 37.71 & 0.48 & 31.43 & 0.76 \\
\hline & $\begin{array}{l}\text { Individual } \\
\text { linear trend }\end{array}$ & -0.12 & 0.45 & $-1.61^{*}$ & 0.05 & 2.36 & 0.99 & $\begin{array}{c}16.36 \\
\text { (chi-square) }\end{array}$ & 1.00 & $\begin{array}{c}13.39 \\
\text { (chi-square) }\end{array}$ & 1.00 \\
\hline \multirow{3}{*}{ Lurbpop } & $\begin{array}{l}\text { Individual } \\
\text { effects }\end{array}$ & $-2.05^{* *}$ & 0.02 & & & 8.07 & 1.00 & $\begin{array}{c}32.31^{* * *} \\
\text { (chi-square) }\end{array}$ & 0.72 & $\begin{array}{c}81.92^{* * *} \\
\text { (chi-square) }\end{array}$ & 0.00 \\
\hline & & & & & & & & & & & \\
\hline & $\begin{array}{l}\text { Individual } \\
\text { linear trend }\end{array}$ & -0.59 & 0.27 & 0.19 & 0.58 & 2.49 & 0.99 & $\begin{array}{c}36.54 \\
\text { (chi-square) }\end{array}$ & 0.53 & $\begin{array}{c}86.02^{* * *} \\
\text { (chi-square) }\end{array}$ & 0.00 \\
\hline
\end{tabular}

Notes: a. One lag assumed for all tests; b. Newey-West automatic bandwidth and Bartlett kernel; c. Sample of 19 countries; d. The null hypothesis of these tests is that the panel series has a unit root (non-stationary series); e. ${ }^{*} 10 \%$ level of significance, ${ }^{* * *} 5 \%$ level of significance, ${ }^{* * * *} 1 \%$ level of significance. Source: Authors own tests (2014).

Cointegration tests) by taking the first difference of the variables, in order to check for the existence of a longrun relationship between them.

\subsection{Panel Cointegration Tests}

The next step is to consider panel cointegration tests in order to investigate the existence of a long-run relationship between the iron and steel importation data, GDP per capita, investment in infrastructure, real effective exchange rates and the number of urban population. Table 3 presents the panel cointegration tests for the unbalanced set. The case was estimated with 1) no trend and no intercept, 2) intercept but no trend and 3) intercept with trend.

The Panel Cointegration tests, which examine the existence of a long-run relationship, are classified into two types: tests based on the Engle-Granger [42] methodology and tests based on the Johansen-Fisher methodology. The Engle-Granger based tests used in this paper are the Pedroni [43] [44] test and Kao [45] test. The JohansenFisher based test [46] is the one proposed by Maddala and $\mathrm{Wu}$ [47].

The different cointegrations tests conducted between the dependent variable and the explanatory variables result in the confirmation of the fact that they are cointegrated, suggesting that there is a long-run relationship between the iron and steel importation data, GDP per capita, and investment in infrastructure, real effective exchange rates and the number of urban population. 
Table 2. Panel unit root tests for the first difference of the variables (unbalanced set).

\begin{tabular}{|c|c|c|c|c|c|c|c|c|c|c|c|}
\hline \multicolumn{12}{|c|}{ Panel Unit root tests (Unbalanced set)—first differences } \\
\hline \multirow{2}{*}{ Variable } & \multirow{2}{*}{ Tests } & \multicolumn{2}{|c|}{ LLC } & \multicolumn{2}{|c|}{ Breitung-t } & \multicolumn{2}{|c|}{ IPS-W } & \multicolumn{2}{|l|}{ ADF } & \multicolumn{2}{|l|}{ PP } \\
\hline & & Stat & Prob & Stat & Prob & Stat & Prob & Stat & Prob & Stat & Prob \\
\hline \multirow{3}{*}{ limp_f } & $\begin{array}{l}\text { Individual } \\
\text { effects }\end{array}$ & $-9.66^{* * *}$ & 0.00 & & & $-9.37^{* * *}$ & 0.00 & $\begin{array}{c}156.00^{* * *} \\
\text { (chi-square) }\end{array}$ & 0.00 & $\begin{array}{c}543.70^{* * * *} \\
\text { (chi-square) }\end{array}$ & 0.00 \\
\hline & & & & & & & & & & & \\
\hline & $\begin{array}{c}\text { Individual } \\
\text { linear trend }\end{array}$ & $-8.58^{* * *}$ & 0.00 & $-7.76^{* * *}$ & 0.00 & $-6.38^{* * * *}$ & 0.00 & $\begin{array}{c}111.75^{* * *} \\
\text { (chi-square) }\end{array}$ & 0.00 & $\begin{array}{c}240.71^{* * * *} \\
\text { (chi-square) }\end{array}$ & 0.00 \\
\hline \multirow{3}{*}{ lgdpcap } & $\begin{array}{l}\text { Individual } \\
\text { effects }\end{array}$ & 1.26 & 0.90 & & & 4.56 & 1.00 & $\begin{array}{c}7.73 \\
\text { (chi-square) }\end{array}$ & 1.00 & $\begin{array}{c}10.36 \\
\text { (chi-square) }\end{array}$ & 1.00 \\
\hline & & & & & & & & & & & \\
\hline & $\begin{array}{l}\text { Individual } \\
\text { linear trend }\end{array}$ & $-1.94^{* * *}$ & 0.03 & $-2.12^{* *}$ & 0.02 & $-1.32^{*}$ & 0.09 & $\begin{array}{c}43.42 \\
\text { (chi-square) }\end{array}$ & 0.25 & $\begin{array}{c}21.57 \\
\text { (chi-square) }\end{array}$ & 0.99 \\
\hline \multirow{3}{*}{ linv } & $\begin{array}{l}\text { Individual } \\
\text { effects }\end{array}$ & $-4.22^{* * *}$ & 0.00 & & & $-5.49^{* * *}$ & 0.00 & $\begin{array}{c}97.77^{* * *} \\
\text { (chi-square) }\end{array}$ & 0.00 & $\begin{array}{l}191.34^{* * *} \\
\text { (chi-square) }\end{array}$ & 0.00 \\
\hline & & & & & & & & & & & \\
\hline & $\begin{array}{l}\text { Individual } \\
\text { linear trend }\end{array}$ & $-3.25^{* * *}$ & 0.00 & -0.54 & 0.29 & $-2.93^{* * *}$ & 0.00 & $\begin{array}{c}69.37^{* * *} \\
\text { (chi-square) }\end{array}$ & 0.00 & $\begin{array}{c}167.54^{* * *} \\
\text { (chi-square) }\end{array}$ & 0.00 \\
\hline \multirow{3}{*}{ ltcer } & $\begin{array}{l}\text { Individual } \\
\text { effects }\end{array}$ & $-8.57^{* * *}$ & 0.00 & & & $-6.33^{* * *}$ & 0.00 & $\begin{array}{c}106.87^{* * *} \\
\text { (chi-square) }\end{array}$ & 0.00 & $\begin{array}{c}197.29^{* * *} \\
\text { (chi-square) }\end{array}$ & 0.00 \\
\hline & & & & & & & & & & & \\
\hline & $\begin{array}{c}\text { Individual } \\
\text { linear trend }\end{array}$ & $-8.36^{* * *}$ & 0.00 & $-8.61^{* * *}$ & 0.00 & $-5.09^{* * *}$ & 0.00 & $\begin{array}{c}88.56^{* * *} \\
\text { (chi-square) }\end{array}$ & 0.00 & $\begin{array}{c}182.35^{* * *} \\
\text { (chi-square) }\end{array}$ & 0.00 \\
\hline \multirow{2}{*}{ lurbpop } & $\begin{array}{l}\text { Individual } \\
\text { effects }\end{array}$ & 0.68 & 0.75 & & & 0.74 & 0.77 & $\begin{array}{c}32.79 \\
\text { (chi-square) }\end{array}$ & 0.71 & $\begin{array}{c}100.05 \\
\text { (chi-square) }\end{array}$ & 0.00 \\
\hline & $\begin{array}{l}\text { Individual } \\
\text { linear trend }\end{array}$ & 2.38 & 0.99 & 5.92 & 1.00 & 0.82 & 0.79 & $\begin{array}{c}40.04 \\
\text { (chi-square) }\end{array}$ & 0.38 & $\begin{array}{l}115.69^{* * * *} \\
\text { (chi-square) }\end{array}$ & 0.00 \\
\hline
\end{tabular}

Notes: a. One lag assumed for all tests; b. Newey-West automatic bandwidth and Bartlett kernel; c. Sample of 19 countries; d. The null hypothesis of these tests is that the panel series has a unit root (non-stationary series); e. ${ }^{*} 10 \%$ level of significance, ${ }^{* *} 5 \%$ level of significance, ${ }^{* * *} 1 \%$ level of significance. Source: Authors own tests (2014).

\subsection{Long-Run Models}

\subsubsection{The Panel Error Correction Model (ECM)}

In the present case, stationary tests in level show that all variables admit a unit root; in first differences, they are stationary. These variables are integrated of order 1 or I (1). Also, different cointegration tests conducted between the dependent variable and the explanatory variables lead to the confirmation of the fact that they are cointegrated. This suggests that the specification of Error Correction Model (ECM) would be suitable for the representation of the theoretical relationship between the explanatory variables and iron and steel importation.

The Error Correction Modeling enables us to jointly model the short-term dynamics represented by the variables in first differences and long-term dynamics represented by the variables in levels. This is of great interest for us as the primordial objective of this study is to estimate the long-term relationship.

The equation of the model to be estimated is then written as follows [42]:

$$
\begin{gathered}
\forall i=1, \cdots, N \text {, et } \forall t=1, \cdots, T \\
\Delta y_{i t}=-\phi \cdot\left(y_{i t-1}-\sum_{j=1}^{4} \theta_{j} \cdot X_{i t-1}^{j}\right)+\sum_{j=1}^{4} \rho_{j} \cdot \Delta X_{i t}^{j}+\vartheta_{i t}
\end{gathered}
$$

And, $\vartheta_{i t}=\alpha_{i}+\varepsilon_{i t}$, where $\varepsilon_{i t} \sim N\left(0, \sigma_{i}^{2}\right)$, the idiosyncratic error (white noise), and $\alpha_{i}$ the individual effects. 
Table 3. Panel cointegration tests (unbalanced set).

\begin{tabular}{|lccc|}
\hline & \multicolumn{2}{c|}{ Panel cointegration tests (Unbalanced set) } \\
\hline import of iron/steel & \multicolumn{2}{c|}{ Explanatory variables: lgdpcap, linv, ltcer, lurbpop } \\
\hline & No trend-no & Intercept without & Intercept with trend \\
\hline & Intercept & Trend & \\
\hline
\end{tabular}

Pedroni residual cointegration tests

Panel statistics

$\begin{array}{cc}\text { Panel-v } & -2.06 \\ \text { p-value } & 0.98 \\ \text { Panel-rho } & 0.75 \\ \text { p-value } & 0.77 \\ \text { Panel-PP } & -6.58^{* * *} \\ \text { p-value } & 0.00 \\ \text { Panel-ADF } & -2.25^{* *} \\ \text { p-value } & 0.01\end{array}$

$\begin{array}{cc}-3.19 & -5.09 \\ 1.00 & 1.00 \\ 1.58 & 2.47 \\ 0.94 & 0.99 \\ -8.98^{* * *} & -12.73^{* * *} \\ 0.00 & 0.00 \\ -2.37^{* * *} & -2.35^{* * *} \\ 0.00 & 0.00\end{array}$

Panel statistics weighted

$\begin{array}{cc}\text { Panel-v } & -2.31 \\ \text { p-value } & 0.99 \\ \text { Panel-rho } & 0.67 \\ \text { p-value } & 0.75 \\ \text { Panel-PP } & -5.58^{* * *} \\ \text { p-value } & 0.00 \\ \text { Panel-ADF } & -3.29^{* * *} \\ \text { p-value } & 0.00\end{array}$

$\begin{array}{cc}-3.28 & -5.28 \\ 1.00 & 1.00 \\ 1.21 & 2.13 \\ 0.89 & 0.98 \\ -8.12^{* * *} & -10.20^{* * *} \\ 0.00 & 0.00 \\ -4.41^{* * *} & -3.75^{* * *} \\ 0.00 & 0.00\end{array}$

Group statistics

$\begin{array}{cc}\text { Group-rho } & 2.32 \\ \text { p-value } & 0.99 \\ \text { Group-PP } & -9.52^{* * * *} \\ \text { p-value } & 0.00 \\ \text { Group-ADF } & -4.13^{* * * *} \\ \text {-value } & 0.00\end{array}$

Kao residual cointegration tests

$\begin{array}{cc}\text { ADF } & -2.52^{* * * *} \\ \text { p-value } & 0.005\end{array}$

Johansen-Fisher panel cointegration test trace test (Fisher Stat)

$\begin{array}{cccc}\text { None } & 357.4^{* * *} & 329.3^{* * *} & 307.5^{* * *} \\ \text { p-value } & 0.00 & 0.00 & 0.00 \\ \text { At most } 1 & 228.7^{* * *} & 269.5^{* * *} & 263.5^{* * *} \\ \text {-value } & 0.00 & 0.00 & 0.00 \\ \text { At most } 2 & 154.0^{* * *} & 920.3^{* * *} & 143.2^{* * *} \\ \text { p-value } & 0.00 & 0.00 & 0.00\end{array}$




\begin{tabular}{cccc} 
Continued & & & \\
\hline At most 3 & $97.72^{* * * *}$ & $108.8^{* * * *}$ & $77.77^{* * *}$ \\
p-value & 0.00 & 0.00 & 0.00 \\
At most 4 & $55.71^{* * * *}$ & $66.05^{* * * *}$ & $67.46^{* * * *}$ \\
p-value & 0.00 & 0.00 & 0.00 \\
Maximum eigenvalue test (Fisher Stat) & & & $20.6 .2^{* * *}$ \\
None & $232.5^{* * *}$ & $229.4^{* * *}$ & 0.00 \\
p-value & 0.00 & 0.00 & $195.1^{* * *}$ \\
At most 1 & $164.5^{* * * *}$ & $174.2^{* * * *}$ & 0.00 \\
$p$-value & 0.00 & 0.00 & $113.4^{* * *}$ \\
At most 2 & $90.68^{* * * *}$ & $877.5^{* * *}$ & 0.00 \\
p-value & 0.00 & 0.00 & $56.83^{* * *}$ \\
At most 3 & $79.35^{* * *}$ & $76.60^{* * *}$ & 0.00 \\
p-value & 0.00 & 0.00 & $67.46^{* * *}$
\end{tabular}

Notes: a. One lag specified for all tests; b. Newey-West automatic bandwidth and Bartlett kernel; c. Sample of 19 countries; d. d.f. corrected Dickey-Fuller residual variances; e. $10 \%$ level of significance, ${ }^{* * *} 5 \%$ level of significance, ${ }^{* * *} 1 \%$ level of significance. Source: Authors own tests (2014).

In the Equation (1), $y_{i t}$ represents the iron and steel importation of the country $i$, of the date $t$, at constant prices of 1995; the $X_{i t}^{j}$ represent the explanatory variables (GDP per capita, the Real Exchange Rate, Investment in Infrastructure, Urban Population).

The coefficients $\theta_{j}$ and $\rho_{j}$, are respectively the long-term elasticity and short-term elasticity.

The estimate of the mathematical relationship (1) gives an adjustment coefficient, $(-\hat{\phi}=-0.586)$ (see Figure 2), significantly negative at $1 \%$ level of significance, translating the validity of the specification of the ECM model; and at the same time, the long-term relationship contained therein can be exploited.

\subsubsection{Long-Term Relationship Using Pooled Mean Group (PMG) Regression Methods}

The adjustment coefficient is significantly negative at $1 \%$ level of significance, ECM specification is valid. Therefore we can consider the long-term relationship estimated in this model to perform our analysis.

But, the short-term causality relationship (causality in the sense of Engle-Granger [48]) is not the subject of special attention;

Figure 3 presents the summary of results of the estimation of the long-term relationship using the Pooled Mean Group (PMG) method.

The Pooled Mean Group (PMG) estimation method has been retained in comparison with the Mean Group (MG) method using Hausman tester (see Figure 4) which confirms that the first method provides consistent estimators of the model coefficients [49] [50].

The importations of iron and steel are positively correlated with all the independent variables of the model. All estimated coefficients are positive and significant at $1 \%$ level of significance (Figure 3).

- Long-Term Relationship between the Importations of Iron and Steel and GDP per capita

The elasticity of the importations of iron and steel relative to GDP per capita is unitary (Figure 3); and the Wald test confirms this result at the 95\% level of confidence (see Table 4).

It means that a $10 \%$ increase in GDP per capita has an impact of the same magnitude on the importations of iron and steel in African countries. Two arguments can be put forward to justify this result: first, the analysis of the relationship between the importations of iron and steel and the GDP per capita may be related to the Keynesian theory of consumption, as these importations are integral part to the consumption of these African countries in capital goods. This theory assumes that poor countries have a consumption-income elasticity very close to 1 (they devote almost all of the increase of their income on consumption); this is consistent with our results. Then 
Pooled Mean Group Regression

(Estimate results saved as pmg)

Pane1 Variable (i) : idpays

Time Variable $(t)$ : annee

\begin{tabular}{|c|c|c|c|c|}
\hline Number & obs & & $=$ & 291 \\
\hline Number & groups & & $=$ & 19 \\
\hline per & group: & $\min$ & $=$ & 11 \\
\hline & & avg & $=$ & 15.3 \\
\hline & & $\max$ & $=$ & 18 \\
\hline
\end{tabular}

Log Likelihood

149.3321

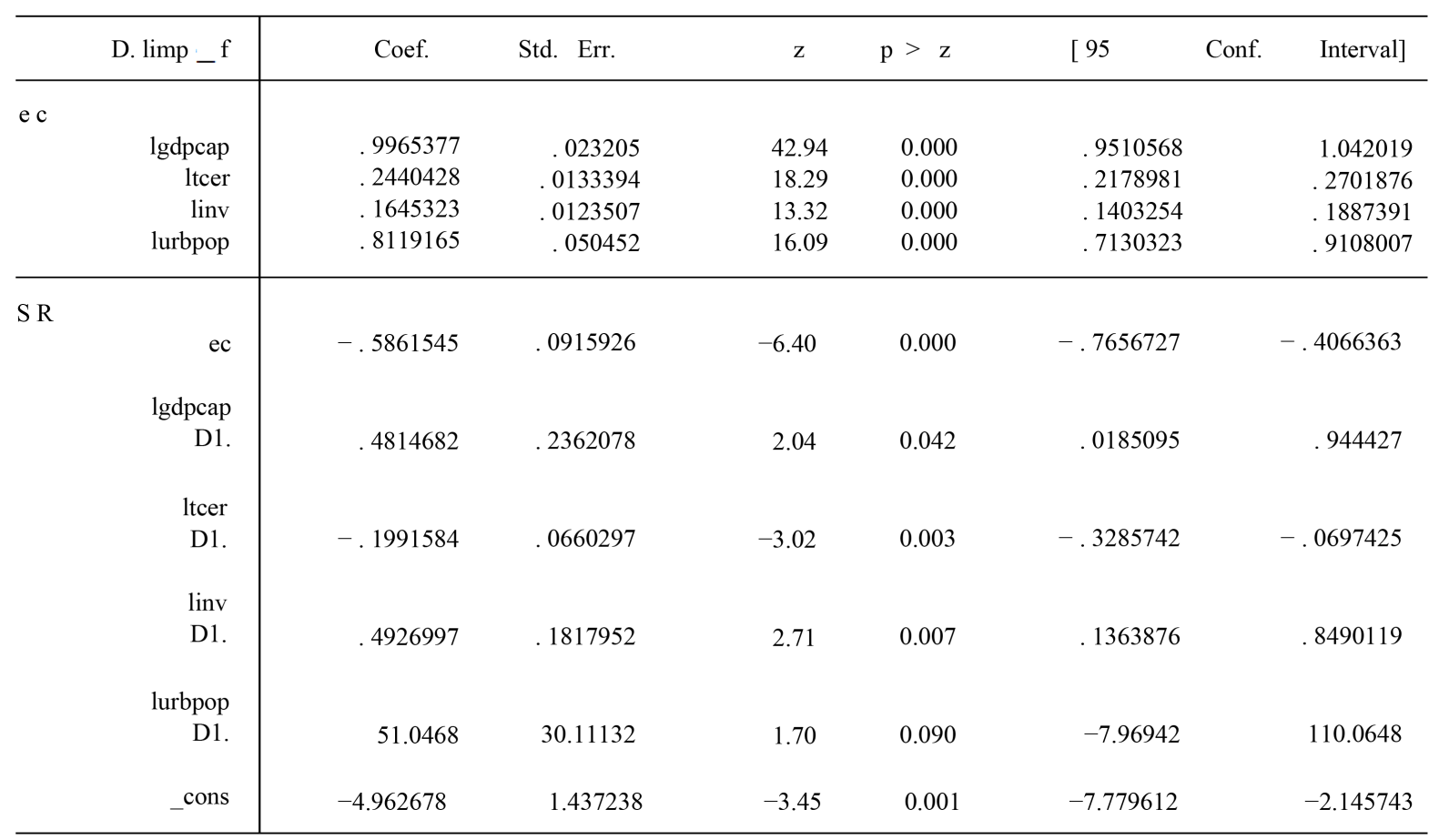

Source: Authors own Estimation (2014)

Figure 2. Estimate results of the pooled mean group regression.

\begin{tabular}{|c|c|c|c|c|c|c|}
\hline $\operatorname{limp\_ f}_{f}$ & Coef. & Std. Err. & $\mathrm{z}$ & $\mathrm{P}>|\mathrm{z}|$ & Conf. & Interval] \\
\hline \multicolumn{7}{|l|}{ ec } \\
\hline lgdpcap & $9965377 * * *$ & .023205 & 42.94 & 0.000 & .9510568 & 1.042019 \\
\hline ltcer & $2440428 * * *$ & .0133394 & 18.29 & 0.000 & .2178981 & .2701876 \\
\hline $\operatorname{linv}$ & $1645323^{* * * *}$ & .0123507 & 13.32 & 0.000 & .1403254 & 1887391 \\
\hline lurbpop & $.8119165 * * *$ & .050452 & 16.09 & 0.000 & .7130323 & 9108007 \\
\hline
\end{tabular}

Notes: ${ }^{* * *} 1 \%$ level of significance. Source: Authors own estimation (2014).

Figure 3. Estimate of the long-term relationship.

the second argument falls within the microeconomic behavior, indeed, GDP per capita is a redistribution of wealth indicator in a given country, it can be considered as the average income of an individual representative of the country. But an African attaches great importance to hard housing construction from the moment he can afford one. This type of accommodation requires the use of large amounts of iron and steel, the increase of hard housing demand, has the effect of increasing the Demand for Iron and Steel Importations (these goods are not produced in the national economy); the increase in hard housing demand following the increase in income. 


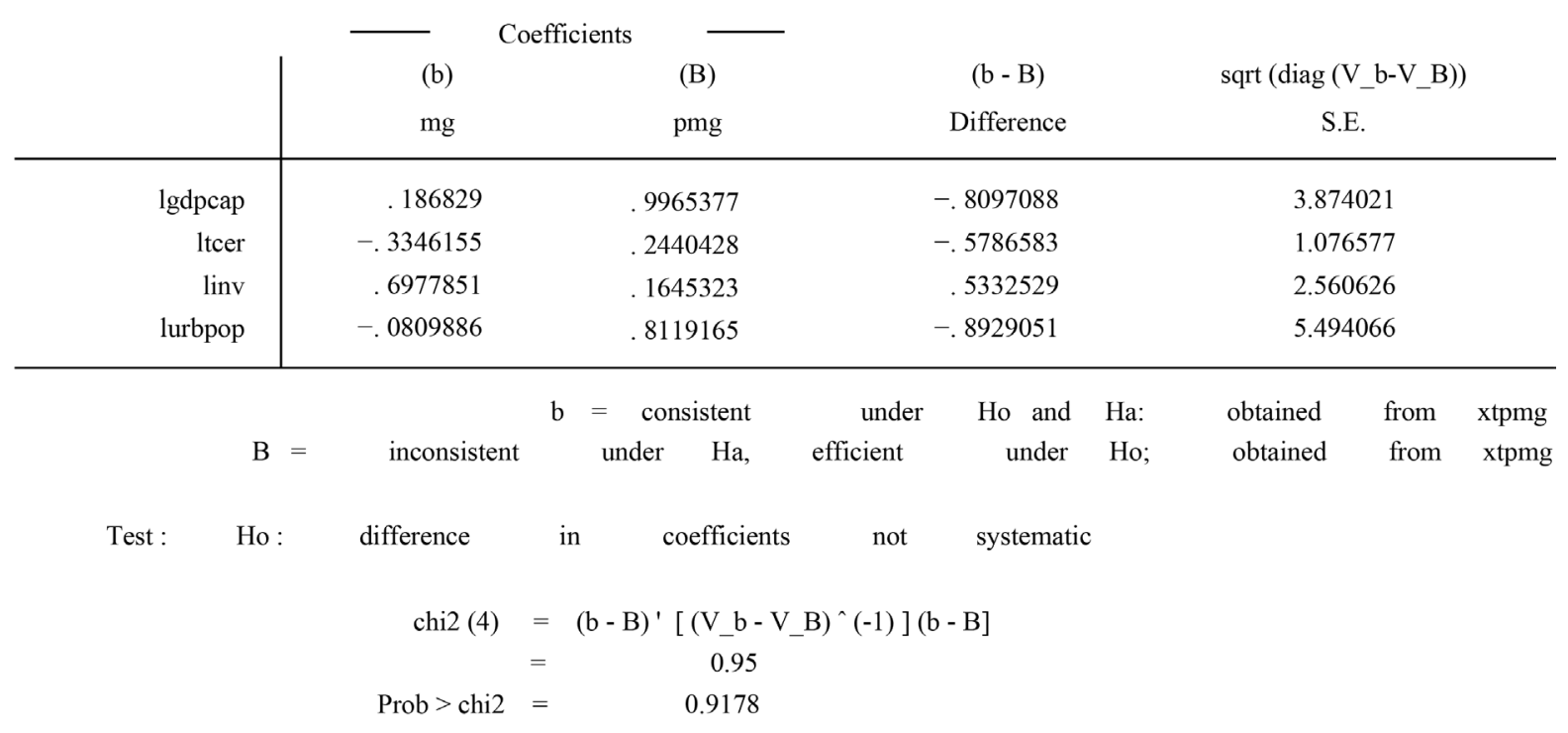

Source: Authors own tests (2014).

Figure 4. Results of hausman tester.

Table 4. Results of wald test.

\begin{tabular}{ccc}
\hline Null hypothesis & Statistic of the test & $p$-value \\
\hline (1) $[$ ec $]$ lgdpcap $=1$ & 0.02 & 0.8814 \\
\hline
\end{tabular}

Source: Authors own tests (2014).

GDP per capita is a key determinant in decisions of Iron and Steel Importations, it represents the term in the equation of Iron and Steel Importations Demand. Hereinafter, we look at the term of price competitiveness of products.

- Long-Term Relationship between the Importations of Iron and Steel and the Real Exchange Rate

Imported products are, to varying degrees, in competition with domestic products; these competitions can take place as well on quality rather than on price. In the present analysis, the qualitative aspect of the competition was occulted to focus on the price aspect. The unavailability of data reflecting the qualitative aspect was a major obstacle to the construction of measurement indicator of quality; therefore it was not taken into account in the analysis. However, the analysis of price competition is carried out through the Real Exchange Rate (REER) (see Appendix). This variable can be interpreted as the ratio of foreign prices to domestic prices, returned in the same currency through the Nominal Effective Exchange Rate (NEER). An appreciation of the real exchange rate results in a faster increase in the level of foreign prices relative to domestic price evolution. This implies that domestic products appear cheaper than foreign goods; domestic goods are more competitive. Demand for imported goods is, therefore, reduced in the benefit of demand for domestic goods. This means that the elasticity of importations relative to the real exchange rate should have a negative sign. However, the estimated value of this elasticity is significantly positive at $1 \%$ level of significance. This result can be interpreted by saying that the REER positively influences the importations of iron and steel. This seems at first sight in contradiction with the presumed sign of this correlation. However, thorough analysis leads to the fact that this contradiction is only apparent. Indeed, African countries are importing of iron and steel for the construction of infrastructure (local production companies' infrastructure, socio-economic infrastructure, buildings and bridges, etc.) necessary for their economic development. These countries do not have the technology, to produce such goods are constrained, in the long term, to maintain (or even increase) their volumes of iron and steel importations although the price of this good have known in rise; there is no local substitutes for such products. Thus, a $1 \%$ increase in the exchange rate leads to an increase in the importations of iron and steel in the range of $0.24 \%$; this elasticity is estimated at 0.244 (Figure 3).

The usual determinants of importations (demand factor and factor price competitiveness) are significant in 
modeling of iron and steel importations and signs are consistent with expectations except the REER. The investment in infrastructure is the focus of the following analysis.

- Long-Term Relationship between the Importations of Iron and Steel and the Infrastructure Investments Infrastructure investments are of paramount importance for the proper functioning of the economy. They refer to transport networks infrastructure (road, rail), energy networks, water and telecommunications. On the one hand, these infrastructures contribute to trade facilitation in the national economy and ensure better performance of countries to foreign trade. On the other hand, the reduction in production costs of enterprises due to improved transport of goods and reduced energy costs used in the production process make these companies more competitive both in the domestic market and on the International market. This situation is likely to favor greater profitability of investment projects; which has the effect of attracting foreign capital in addition to the national capital, in the context of open economies, to finance these investment projects. The increase in demand for investment in infrastructure influences the increase in importations of iron and steel given that construction of these infrastructures (local businesses production infrastructures, housings, bridges and buildings, etc.) use of huge amounts of iron and steel. This result means that iron and steel importations are positively correlated with infrastructure investment.

The elasticity of iron and steel importations relative to infrastructure investment is significant and positive sign at $1 \%$ level of significance. A variation to the rise in infrastructure investment of $10 \%$ positively influences the rise of iron and steel importations about 1.65\%-the estimated value of this elasticity being 0.1645 (Figure 3).

Infrastructure investments vary in the same direction with the expenditures of iron and steel importations in African countries. We are now seeking to establish the causality relationship between the dependent variable and the urban population. This last aspect is the subject of the following analysis.

- Long-Term Relationship between the Importations of Iron and Steel and the Urban Population

The rural exodus to the big cities is a widespread phenomenon in general in developing countries, and particularly in African countries. This is a direct consequence of inequality levels of developments within countries proving the ineffective policies in the coordination and harmonization of development projects. Populations move to big cities looking for a job, looking for best secure and better equipped places in matters of education and health infrastructures. The increase in urban population is not only due to the growth of the urban population, but it can also result from population movements in those countries. This creates a faster evolution of the growth of the urban population compared to the capacity of the major cities on infrastructures. These puts upward pressure on the demand for socio-economic infrastructures and oblige governments to devote enormous resources to finance the construction of these infrastructures; which widening the gap between the levels of development of the cities and other localities, and help making the urban more attractive to farmers. The growth of the urban population thus increases imports of iron and steel by the channel of socio-economic infrastructure demand. These two variables move in the same direction.

The elasticity of iron and steel importations relative to the urban population is significantly positive at $1 \%$ level of significance, and estimated at 0.812 . An increase of $10 \%$ of the urban population leads to an increase of $8.12 \%$ of iron and steel importations (Figure 3).

\section{Conclusions}

In this study, the data used are observations of macroeconomic variables, such as GDP per capita, the index of consumer prices, import iron, the real effective exchange rate, the number of urban population, imports and exports total made on 19 African countries. These observations were made over a period of 19 years from 1994 to 2012. We consider the long-term relationship that may exist between the iron and steel importations and the explanatory variables used (GDP per capita, investment in infrastructure, real effective exchange rate, and the number of urban population).

The general conclusion that can be revealed from the panel unit root tests and stationary tests are that all variables have a unit root; in first differences, they are stationary, these variables are integrated of order 1 or I (1) and the level of the variables are I (1), so we can carry out the second part of the empirical analysis (Panel Cointegration tests) by taking the first difference of the variables, in order to check for the existence of a long-run relationship between them.

The different cointegrations tests conducted between the dependent variable and the explanatory variables result in the confirmation of the fact that they are cointegrated, suggesting that there is a long-run relationship be- 
tween the iron and steel importation data, GDP per capita, and investment in infrastructure, real effective exchange rate and the number of urban population. Moreover also suggests that the specification of Error Correction Model (ECM) would be suitable for the representation of the theoretical relationship between the explanatory variables and iron and steel importation.

The Pooled Mean Group (PMG) estimation method has been retained in comparison with the Mean Group (MG) method using Hausman tester (see Figure 4) which confirms that the first method provides consistent estimators of the model coefficients.

The adjustment coefficient is $(-\hat{\phi}=-0.586)$, significantly negative at $1 \%$ level of significance, Error Correction Modeling (ECM) specification is valid. Therefore we can consider the long-term relationship estimated in this model to perform our analysis. The Importations of iron and steel are positively correlated with all the independent variables of the model. All estimated coefficients are positive and significant at $1 \%$ level of significance. The elasticity of the importations of iron and steel relative to GDP per capita is unitary; indeed the Wald test confirms this result at the 95\% level of confidence (see Table 4). It means that a $10 \%$ increase in GDP per capita has an impact of the same magnitude on the importations of iron and steel in African countries. However, the estimated value of the elasticity real effective exchange rate relative to the importations of iron and steel is significantly positive at $1 \%$ level of significance. This result can be interpreted by saying that the REER positively influences the importations of iron and steel. These countries do not have the technology; to produce such goods are constrained, in the long term, to maintain (or even increase) their volumes of iron and steel importations although the price of this good have known a rise; so there is no local substitutes for such products. Thus, a $1 \%$ increase in the exchange rate leads to an increase in the importations of iron and steel in the range of $0.24 \%$; this elasticity is estimated at 0.244 . The elasticity of iron and steel importations relative to infrastructure investment is significant and positive sign at $1 \%$ level of significance. A variation to the rise in infrastructure investment of $10 \%$ positively influences the rise of iron and steel importations about $1.65 \%$ - the estimated value of this elasticity being 0.1645 . Finally, the elasticity of iron and steel importations relative to the urban population is significantly positive at $1 \%$ level of significance, and estimated at 0.812 . An increase of $10 \%$ of the urban population leads to an increase of $8.12 \%$ of iron and steel importations.

The usual determinants of importations (demand factor and factor price competitiveness) are significant in modeling of iron and steel importations and signs are consistent with expectations except the real effective exchange rate.

\section{Acknowledgements}

I would like to express my special thanks to Professor Yan Liang, Dean of School of Economics and Management for his expertise and professional supervision. I would like also to express all my gratitude to the International Education College, China University of Geosciences (Wuhan) as thanks from Madagascar community, for their support to all Madagascar Students. I also express my special thanks to the government of PR-China and the government of Madagascar, for their financial support, to the International Trade and Economics Department of Wuhan Iron and Steel Corporation for heir high collaboration and contributions during this research. I also express my special thanks to RIVOMANANTSOA John Georgio and my cousin RAVELOMANANA Bernet Chasson for their expertise reviews of the validity of these Models. And finally, I also express my gratitude to all my family members in Madagascar for their support.

\section{References}

[1] Jeannet, J.P. and Hennessey, H.D. (1998) International Marketing Management: Strategies and Cases. Houghton Mifflin, Boston.

[2] Brewer, P. (2000) International Market Selection: Developing a Model from Australian Case Studies. International Business Review, 10, 155-174. http://dx.doi.org/10.1016/S0969-5931(00)00049-4

[3] Papadopoulos, N. and Denis, J.E. (1988) Inventory, Taxonomy and Assessment of Methods for International Market Selection. International Marketing Review, 5, 38-51. http://dx.doi.org/10.1108/eb008357

[4] Pezeshkpur, C. (1979) Systematic Approach to Finding Export Opportunities. Harvard Business Review, 57, $182-196$.

[5] Douglas, S.P. and Craig, C.S. (1992) Advances in International Marketing. International Journal of Research in Marketing, 9, 291-318. http://dx.doi.org/10.1016/0167-8116(92)90002-3

[6] Steenkamp, J.E.M. and Ter Hofstede, F. (2002) International Market Segmentations: Issues and Perspectives. Inter- 
national Journal of Research in Marketing, 19, 185-213. http://dx.doi.org/10.1016/S0167-8116(02)00076-9

[7] Shankarmahesh, M.N., Olsen, H.W. and Honeycutt, E.D. (2005) A Dominant Product-Dominant Country Framework of Industrial Export Segmentation. Industrial Marketing Management, 34, 203-210. http://dx.doi.org/10.1016/j.indmarman.2004.09.002

[8] Sakarya, S., Eckman, M. and Hyllegard, K.H. (2007) Market Selection for International Expansion: Assessing Opportunities in Emerging Markets. International Marketing Review, 24, 208-238. http://dx.doi.org/10.1108/02651330710741820

[9] Kumar, V., Stam, A. and Joachimsthaler, E.A. (1993) An Interactive Multi-Criteria Approach to Identifying Potential Foreign Markets. Journal of International Marketing, 2, 29-52.

[10] Ayal, I. and Zif, J. (1978) Competitive Market Choice Strategies in Multinational Marketing. Columbia Journal of World Business, 13, 72-81.

[11] Davidson, W.H. (1983) Market Similarity and Market Selection: Implications for International Marketing Strategy. Journal of Business Research, 11, 439-456. http://dx.doi.org/10.1016/0148-2963(83)90004-8

[12] Cavusgil, S.T. (1985) Guidelines for Export Market Research. Business Horizons, 28, 27-33. http://dx.doi.org/10.1016/0007-6813(85)90082-5

[13] Hoffman, J.J. (1997) A Two Stage Model for the Introduction of Products into International Markets. Journal of Global Marketing, 11, 67-86. http://dx.doi.org/10.1300/J042v11n01 05

[14] Andersen, P.H. and Strandskov, J. (1998) International Market Selection: A Cognitive Mapping Perspective. Journal of Global Marketing, 11, 65-84. http://dx.doi.org/10.1300/J042v11n03_05

[15] Andersen, O. and Buvik, A. (2002) Firms' Internationalisation and Alternative Approaches to the International Customer/Market Selection. International Business Review, 11, 347-363. http://dx.doi.org/10.1016/S0969-5931(01)00064-6

[16] Rahman, S.H. (2003) Modelling of International Market Selection Process: A Qualitative Study of Successful Australian International Businesses. Qualitative Market Research: An International Journal, 6, 119-132. http://dx.doi.org/10.1108/13522750310470127

[17] Alon, I. (2004) International Market Selection for a Small Enterprise: A Case Study in International Entrepreneurship. SAM Advanced Management Journal, 69, 25-33.

[18] Ozorhon, B., Dikmen, I. and Birgonul, M.T. (2006) Case-Based Reasoning Model for International Market Selection. Journal of Construction Engineering and Management, 132, 940-947. http://dx.doi.org/10.1061/(ASCE)0733-9364(2006)132:9(940)

[19] Viviers, W. and Pearson, J.J.A.P. (2007) The Construction of a Decision Support Model for Evaluating and Identifying Realistic Export Opportunities in South Africa. Report Prepared for the Department of Trade and Industry, South Africa, May, 92 p. (Unpublished)

[20] Viviers, W., Rossouw, R. and Steenkamp, E.A. (2009) The Sustainability of the DSM for Identifying Realistic Export Opportunities for South-Africa: 2007-2008. Report Prepared for the Department of Trade and Industry, South Africa, February, 105 p. (Unpublished)

[21] Viviers, W., Steenkamp, E.A. and Rossouw, R. (2010) Identification Realistic Export Opportunities for South Africa: Application of a Decision Support Model (DSM) Using HS 6-Digit Level Product Data. Report Prepared for the Department of Trade and Industry, South Africa, September, 57 p. (Unpublished)

[22] Green, R.T. and Allaway, A.W. (1985) Identification of Export Opportunities: A Shift-Share Approach. Journal of Marketing, 49, 83-88. http://dx.doi.org/10.2307/1251178

[23] Russow, L.C. and Ond, S.C. (1996) On the Way towards Developing a Global Screening Model. International Marketing Review, 13, 46-64. http://dx.doi.org/10.1108/02651339610111344

[24] Papadopoulos, N., Chen, H. and Thomans, D.R. (2002) Toward a Tradeoff Model for International Market Selection. International Business Review, 11, 165-192. http://dx.doi.org/10.1016/S0969-5931(01)00054-3

[25] Freudenberg, M. and Paulmier, T. (2005) Export Potential Assessment in Vietnam. (Unpublished Report of the International Trade Centre, Market Analysis Section)

[26] Freudenberg, M. and Paulmier, T. (2005) Export Potential Assessment in Lao PDR. (Unpublished Report of the International Trade Centre, Market Analysis Section)

[27] Freudenberg, M., Paulmier, T., Bijl, B. and Ikezuki, T. (2007) Export Potential Assessment in Nepal. (Unpublished Report of the International Trade Centre, Market Analysis Section)

[28] Freudenberg, M., Paulmier, T., Ikezuki, T. and Conte, K. (2008) Export Opportunity Scan for Jordan: Second Draft. (Unpublished Report of the International Trade Centre, Market Analysis Section)

[29] Arnold, D.J. and Quelsh, J.A. (1998) New Strategies in Emerging Markets. Sloan Management Review, 40, 7-20. 
[30] Cavusgil, S.T. (1985) Guidelines for Export Market Research. Business Horizons, 28, 27-33. http://dx.doi.org/10.1016/0007-6813(85)90082-5

[31] Cavusgil, S.T. (1997) Measuring the Potential of Emerging Markets: An Indexing Approach. Business Horizons, 40, 87-91.

[32] Alon, I. (2004) International Market Selection for a Small Enterprise: A Case Study in International Entrepreneurship. SAM Advanced Management Journal, 69, 25-33.

[33] Verno, C. (2008) The Trade Opportunity Matrix (TOM): An Overview of Canadian Export Opportunities. http://www.edc.ca/english/docs/TOM_Final_Report_Dec2008_e.pdf

[34] Banerjee, A. (1999) Panel Data Unit Roots and Co-Integration: An Overview. Oxford Bulletin of Economics and Statistics, 61, 607-629. http://dx.doi.org/10.1111/1468-0084.61.s1.12

[35] Boumahdi, R. and Thomas, A. (1991) Testing for Unit Roots Using Panel Data. Economics Letters, 37, 77-79. http://dx.doi.org/10.1016/0165-1765(91)90246-H

[36] Holden, D. and Perman, R. (1994) Unit Roots and Co-Integration for the Economist. In: Rao, B.B., Ed., Co-Integration for the Applied Economist, St. Martin's Press, New York.

[37] Levin, A., Lin, C.F. and Chu, C. (2002) Unit Root Test in Panel Data: Asymptotic and Finite Sample Properties. Journal of Econometrics, 108, 1-25. http://dx.doi.org/10.1016/S0304-4076(01)00098-7

[38] Breitung, J. (2000) The Local Power of Some Unit Root Tests for Panel Data. Advances in Econometrics, 15, $161-177$. http://dx.doi.org/10.1016/S0731-9053(00)15006-6

[39] Im, K.S., Pesaran, M.H. and Shin, Y. (2003) Testing for Unit Roots in Heterogeneous Panels. Journal of Econometrics, 115, 53-74. http://dx.doi.org/10.1016/S0304-4076(03)00092-7

[40] Fisher, F.M. (1970) Tests of Equality between Sets of Coefficients in Two Linear Regressions: An Expository Note. Econometrica, 38, 361-366. http://dx.doi.org/10.2307/1913018

[41] Fuller, W.A. and Battese, G.E. (1974) Estimation of Linear Models with Cross-Error Structure. Journal of Econometrics, 2, 67-78. http://dx.doi.org/10.1016/0304-4076(74)90030-X

[42] Engle, R.F. and Granger, C.W.J. (1987) Cointegration and Error Correction: Representation, Estimation and Testing. Econometrica, 55, 251-276. http://dx.doi.org/10.2307/1913236

[43] Pedroni, P. (1999) Critical Values for Co-Integration Tests in Heterogeneous Panels with Multiple Regressors. Oxford Bulletin of Economics and Statistics, 61, 653-678. http://dx.doi.org/10.1111/1468-0084.61.s1.14

[44] Pedroni, P. (2004) Panel Co-Integration: Asymptotic and Finite Sample Properties of Pooled Time Series Tests with an Application to the PPP Hypothesis. Econometric Theory, 20, 597-625. http://dx.doi.org/10.1017/S0266466604203073

[45] Kao, C. and Chiang, M.H. (2000) On the Estimation and Inference of a Co-Integrated Regression in Panel Data. Advances in Econometrics, 15, 179-222. http://dx.doi.org/10.1016/S0731-9053(00)15007-8

[46] Johansen, S. (1995) Likelihood-Based Inference in Co-Integrated Vector Autoregressive Models. Oxford University Press, Oxford. http://dx.doi.org/10.1093/0198774508.001.0001

[47] Maddala, G.S. and Wu, S. (1999) A Comparative Study of Unit Root Tests with Panel Data and a New Simple Test. Oxford Bulletin of Economics and Statistics, 61, 631-652. http://dx.doi.org/10.1111/1468-0084.61.s1.13

[48] Granger, C.W.J. (1988) Causality, Co-Integration and Control. Journal of Economic Dynamics and Control, 12, 551-559. http://dx.doi.org/10.1016/0165-1889(88)90055-3

[49] Baltagi, B.H., Griffin, J.M. and Xiong, W. (2000) To Pool or Not to Pool: Homogeneous versus Heterogeneous Estimators Applied to Cigarette Demand. Review of Economics and Statistics, 82, 117-126. http://dx.doi.org/10.1162/003465300558551

[50] Pesaran, M.H., Shin, Y. and Smith, R. (1999) Pooled Mean Group Estimation of Dynamic Heterogeneous Panels. Journal of the American Statistical Association, 94, 621-634. http://dx.doi.org/10.1080/01621459.1999.10474156 


\section{Appendix}

\section{Multilateral Nominal Exchange Rate: NEER}

Let given a period $t, e_{j t}$ is the exchange rate of the partner countries of the African country $i$ quoted on the uncertain. The partner countries are the USA, France, Germany, Italy, Spain, Great Britain, and China.

$$
\begin{aligned}
& 1 \$=e_{\mathrm{USA}}(t) \mathrm{LCU} ; 1 £=e_{\mathrm{GB}}(t) \mathrm{LCU} ; 1 \mathrm{YUAN}=e_{\mathrm{CHN}}(t) \mathrm{LCU} ; \\
& 1 €=e_{\mathrm{FRA}}(t) \mathrm{LCU}=e_{\mathrm{DEU}}(t) \mathrm{LCU}=e_{\mathrm{ITA}}(t) \mathrm{LCU}=e_{\mathrm{ESP}}(t) \mathrm{LCU} ; \\
& \operatorname{NEER}_{i t}=\prod_{j \leq n} e_{j t}^{w_{j t}}
\end{aligned}
$$

$n$ number of partner countries

$$
w_{j t} \text { Market share such as } w_{j t}=\frac{X_{j t}+M_{i t}}{\sum_{j}\left(X_{j t}+M_{j t}\right)}
$$

$J$ belongs to the ensemble \{China, France, Germany, Italy, Spain, United States, United States\}. Where $X_{i}$ represents the exportation of countries i to the African country and $M_{i t}$ importation.

Calculation of Foreign Prices Index FPI

$$
\mathrm{FPI}_{i t}=\prod_{j \leq n} p_{j t}^{w_{j t}}
$$

$\mathrm{FPI}_{i t}=\prod_{j \leq n} p_{j t}^{w_{j t}} \quad$ where $p_{i t}$ is the DPI of partner country

$\operatorname{DPI}(t)$ : domestic price index

\section{Calculation of REER: Real Effective Exchange Rate}

$$
\operatorname{REER}(t)=\operatorname{NEER}(t) * \operatorname{FPI}(t) / \operatorname{DPI}(t)
$$

DPI: domestic price index of African countries FPI: foreign prices index

LCU: local currency 
Scientific Research Publishing (SCIRP) is one of the largest Open Access journal publishers. It is currently publishing more than 200 open access, online, peer-reviewed journals covering a wide range of academic disciplines. SCIRP serves the worldwide academic communities and contributes to the progress and application of science with its publication.

Other selected journals from SCIRP are listed as below. Submit your manuscript to us via either submit@scirp.org or Online Submission Portal.
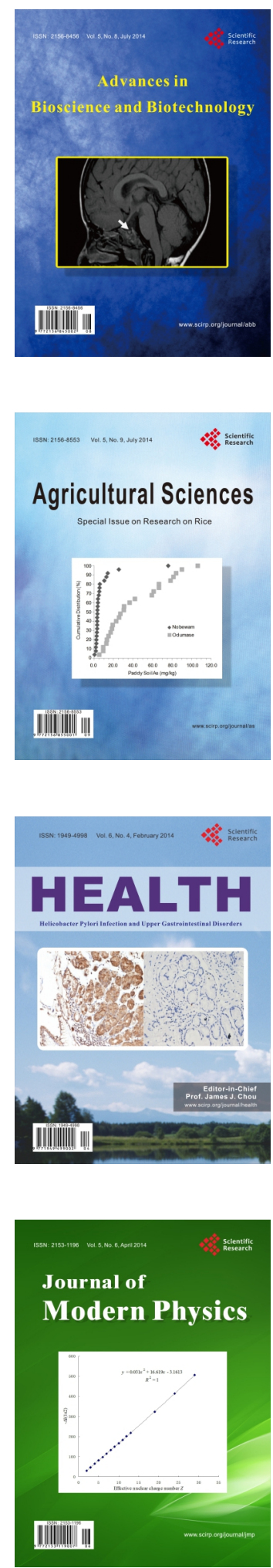
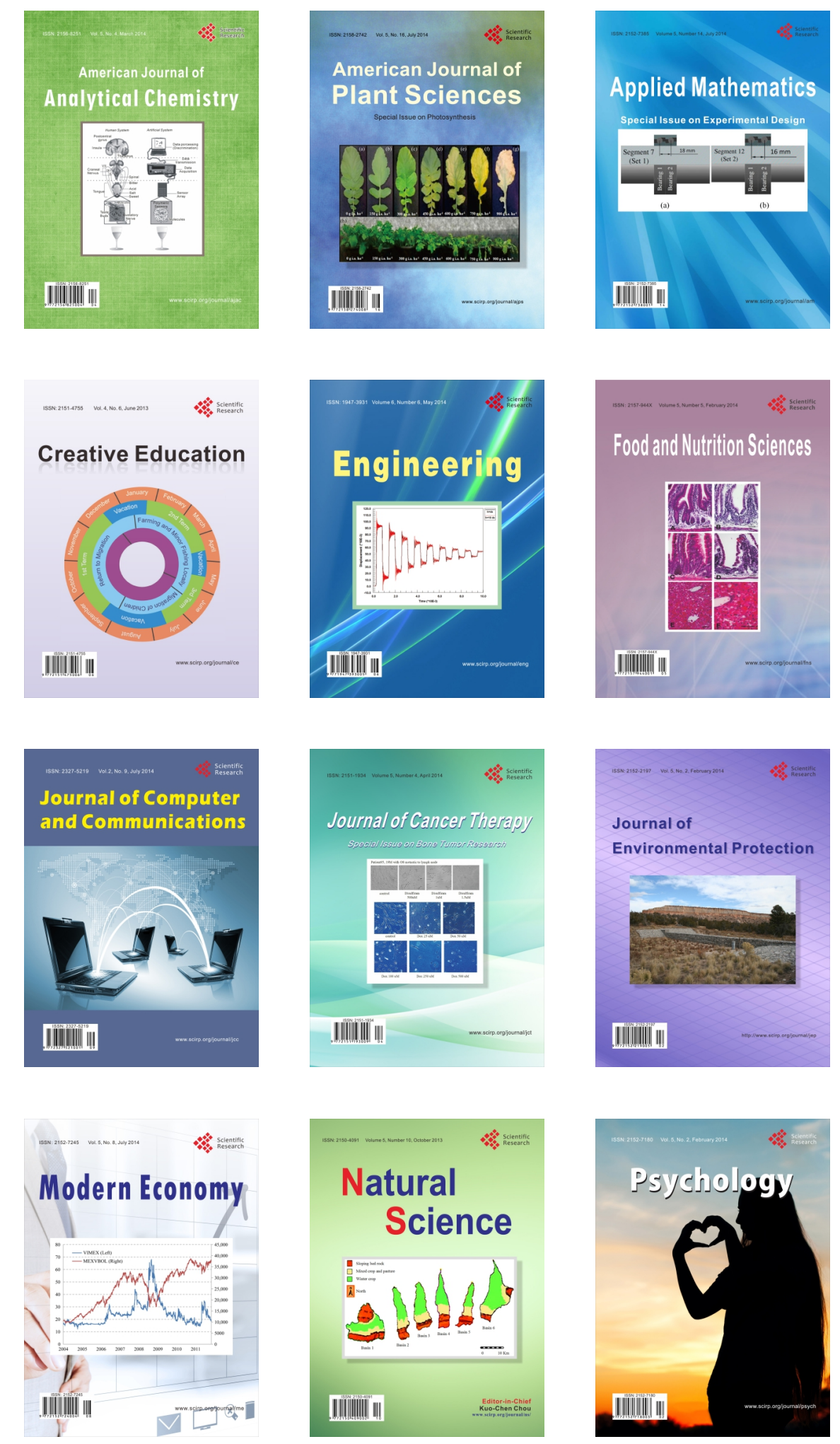